\title{
THE RISK OF DEVELOPING A CONTACT ALLERGY TO MATERIALS PRESENT IN DIVING SUITS AND DIVING EQUIPMENT
}

\author{
Krzysztof Gadomski ${ }^{1}$, Piotr Siermontowski ${ }^{2)}$, Zbigniew Dąbrowiecki $^{2)}$, Romuald Olszaski ${ }^{2)}$ \\ 1) Military Preventive Medicine Centre, Gdynia, Poland \\ 2) Maritime and Hyperbaric Medicine Department of the Military Institute of Medicine of Gdynia, Poland
}

\begin{abstract}
Allergic contact eczema is the most common occupational skin disease caused by allergens. Thus far, no research has been conducted in Poland in relation to the development of contact allergies amongst divers resulting from particular diving suit components. A group of 86 divers were examined using allergy patch tests. Standard products of contact allergy diagnostics were used containing 40 allergens.

Keywords: Allergic contact dermatitis, allergens, diving suit, diving, patch tests.
\end{abstract}

ARTICLE INFO

PolHypRes 2017 Vol. 58 Issue 2 pp. 57 - 60

ISSN: 1734-7009 eISSN: 2084-0535

Original article

DOI: $10.1515 /$ phr-2017-0008

Pages: 4, figures: 0 , tables: 1

Submission date: 13.12 .2016

page www of the periodical: www.phr.net.pl

Acceptance for print: 03.04.2017

Publisher

Polish Hyperbaric Medicine and Technology Society 


\section{INTRODUCTION}

Skin diseases account for as much as $40 \%$ of all reported occupational diseases in most European countries. Allergic contact eczema is the most common occupational skin disease [1]. Other descriptions are contact eczema allergy or allergic contact dermatitis. They should be distinguished from non-allergic contact dermatitis (resulting from skin irritation).

Allergic skin contact eczema constitutes the fourth type of allergic reaction i.e. the so-called delayed response. The most common contact allergens include: nickel, chromium, cobalt, rubber components (latex, vulcanisation accelerators, antioxidants), dyes, paragroup compounds, epoxy resins, external drugs, formalin, cosmetics.

For proper prevention and treatment of allergic contact dermatitis allergen identification is essential. Patch tests should be performed as a standard procedure in order to confirm the diagnosis $[1,2]$.

There is an observable increase in the incidence of allergic diseases, including allergic contact dermatitis $[1,2]$. Thus far no research has been conducted in Poland on the frequency of contact allergies resulting from diving suit components. World literature describes only isolated cases of allergic contact eczema in divers $[3,4,5]$.

\section{RESEARCH OBJECTIVE}

- Detection of allergies to diving suit components among professional divers using patch tests.

- Preventive actions - patch tests used as an additional test during diver qualification tests at the Military Maritime Medical Commission.

\section{MATERIAL AND METHOD}

Patch tests were performed on 86 divers aged between 18 and 50 years of age. The divers who qualified for testing were those who had worn their suits for at least 50 hours whilst performing dives.

Following the medical examination and signing of the consent for testing, patch tests containing 40 allergens were placed on the divers' backs. The list of test substances (allergens) is shown in Table 1.

The list of test substances (allergens).

\begin{tabular}{|c|c|}
\hline Test substance & Test substance \\
\hline Tiuram, TMTD Accelerator $1 \% \mathrm{w} / \mathrm{w}$ & 2,2,4-Trimethyl-1,2-dihydroquinoline $1 \% \mathrm{w} / \mathrm{w}$ \\
\hline Tetramethylthiuram monosulfide $1 \% \mathrm{w} / \mathrm{w}$ & Diethylthiourea, DETU 1\% w/w \\
\hline Tetramethylthiuram disulfide $1 \% \mathrm{w} / \mathrm{w}$ & Dibutylthiourea, DBTU 1\% w/w \\
\hline Dipentamethylenethiuram disulphide $1 \% \mathrm{w} / \mathrm{w}$ & Dodecylmercaptan $1 \% \mathrm{w} / \mathrm{w}$ \\
\hline $\begin{array}{l}\mathrm{N}-\text { cyclohexyl-N-phenyl-4-phenylenediamine } \\
\mathrm{w} / \mathrm{w}\end{array}$ & $\mathrm{N}$-cyclohexylthio phthalimide, $1 \% \mathrm{w} / \mathrm{w}$ \\
\hline $\mathrm{N}, \mathrm{N}$-Diphenyl-4-phenylenediamine $1 \% \mathrm{w} / \mathrm{w}$ & 4-tert-butyl formaldehyde resin $1 \% \mathrm{w} / \mathrm{w}$ \\
\hline $\begin{array}{ll}\text { N-isopropyl-N-phenyl-4-phenylenediamine } & 0.1 \% \\
w / w\end{array}$ & epoxyde resin $25 \% \mathrm{w} / \mathrm{w}$ \\
\hline 2-Mercaptobenzothiazole, MBT, 2\% w/w & Thiourea $0.1 \% \mathrm{w} / \mathrm{w}$ \\
\hline $\begin{array}{l}\text { N-cyclohexyl-2-benzothiazolesulfenamide; CBS } 1 \% \\
\mathrm{w} / \mathrm{w}\end{array}$ & Paraben mix $16 \% \mathrm{w} / \mathrm{w}$ \\
\hline 2.5-diaminotoluene sulfate $1 \% \mathrm{w} / \mathrm{w}$ & 2-hydroxyethyl-methacrylate, HEMA 2\% w/w \\
\hline $\begin{array}{l}\text { 2-(4-Morpholinylmercapto) benzothiazole MOR 1\% } \\
\mathrm{w} / \mathrm{w}\end{array}$ & Nickel sulfate $5 \% \mathrm{w} / \mathrm{w}$ \\
\hline $\mathrm{N}, \mathrm{N}$-diphenylguanidine, DPG $1 \% \mathrm{w} / \mathrm{w}$ & Copper sulfate $2 \% \mathrm{w} / \mathrm{w}$ \\
\hline Zinc diethyldithiocarbamate $1 \% \mathrm{w} / \mathrm{w}$ & Potassium dichromate $0.5 \% \mathrm{w} / \mathrm{w}$ \\
\hline Zinc dibutyldithiocarbamate, ZDBC 1\% w/w & Cobalt chloride $1 \% \mathrm{w} / \mathrm{w}$ \\
\hline $\mathrm{N}, \mathrm{N}$-dibetanaphthyl-4-phenylenediamine, $1 \% \mathrm{w} / \mathrm{w}$ & Fragrance blend I $8 \% \mathrm{w} / \mathrm{w}$ \\
\hline N-phenyl-2-naphthylamine $1 \% \mathrm{w} / \mathrm{w}$ & Fragrance blend II $14 \% \mathrm{w} / \mathrm{w}$ \\
\hline Hexamethylenetetramine; Urotropin; 2\% w/w & Propolis $10 \% \mathrm{w} / \mathrm{w}$ \\
\hline 4,4'-Diaminodiphenylmethane, $0.5 \% \mathrm{w} / \mathrm{w}$ & Balsam of Peru $25 \% \mathrm{w} / \mathrm{w}$ \\
\hline $\mathrm{N}, \mathrm{N}^{\prime}$-diphenylthiourea $1 \% \mathrm{w} / \mathrm{w}$ & Neomycin sulfate $20 \% \mathrm{w} / \mathrm{w}$ \\
\hline Zinc dimethyldithiocarbamate $1 \% \mathrm{w} / \mathrm{w}$ & 4-phenylenediamine, $1 \% \mathrm{w} / \mathrm{w}$ \\
\hline
\end{tabular}


Standard contact allergy diagnostic products were used: IQ Ultra chambers and patch test components ("Rubber" series and additives) from Chemotechnique Diagnostics (Sweden). Patch tests components were applied on the divers' skin in quantities of $20 \mu \mathrm{l}$ of $1-5 \%$ ointment and left for 48 hours.

\section{RESULTS}

Patch tests have been used for over 100 years and are currently the "gold standard" in the detection of a contact allergies $[6,7]$. This method is characterised by a very good safety profile and is routinely used even on children. In the case of individuals allergic to one or more allergens, an intensification of eczema symptoms is sometimes observed. The exposure to allergens also occurs in divers. This is related to the use of wet or dry waterproof suits, masks andmouthpieces made of rubber or plastics $[3,4,5]$.

A total of 86 divers were tested, contact allergies being detected in 2 divers (one revealed a contact allergy to nickel, the other to chromium).

\section{DISCUSSION}

The pathogenesis of allergic contact dermatitis involves general and local factors [1,2]. General factors include genetic predispositions. Local factors mainly include skin lesions that facilitate disturbance of the "epidermal barrier" and the allergen penetration into the skin. These include mechanical abrasion of the epidermis, maceration under the influence of water /sweat. Also, damage to the epidermis occurs in the course of various skin infections, which is predisposed by a prolonged stay in a diving suit $[3,4,5]$.

The incidence of contact allergies is estimated in various studies to range from 1 to $10 \%[1,2]$. The obtained data did not confirm an increased incidence of contact allergies in divers (only $2 \%$ ).
This proves, inter alia, the proper selection of materials and chemicals used in the production of diving equipment as well as the use of an appropriate qualification procedure for the profession of a diver by the Military Maritime-Medical Commission.

The research identified allergies to diving suits components in only 2 cases. However, it is advisable to extend supplementary tests with allergy patch tests in the medical qualification of professional diver candidates. Detection of a tendency to develop contact dermatitis to any of the components of a diving suit should result in disqualification as a candidate for this profession. In a person who is allergic even to a single allergen, there is a risk of developing allergic reactions to other allergens.

Thanks to the study we will avoid the timeconsuming and costly training of a diver who will soon have to resign from the diving practice, with possible further consequences once a chronic skin disease occurs.

\section{ConClusions}

- The conducted tests identified two positive results to allergens present in metal components of diver equipment and some suits.

- Contact allergy to a single allergen is associated with a very high likelihood of an occurrence of allergic reactions to other substances in the years to come.

- The use of patch tests during the health qualification at the Military Maritime-Medical Commission would allow the exclusion from diving of candidates revealing an allergy to diving suit components, as well as other common allergens indicating the risk of further development of allergic contact eczema.

\title{
BIBLIOGRAPHY
}

1. Alfonso JH, Bauer A, Bensefa-Colas L, Boman A, Bubas M, Constandt L, Crepy MN, Goncalo M, Macan J, Mahler V, Mijakoski D, Ramada Rodilla JM, Rustemeyer T, Spring P, John SM, Uter W, Wilkinson M, Giménez-Arnau AM. Minimum standards on prevention, diagnosis and treatment of occupational and work-related skin diseases in Europe - position paper of the COST Action StanDerm (TD 1206). J Eur Acad Dermatol Venereol. 2017;31 Suppl 4:31-43.

2. Chen JK, Jacob SE, Nedorost ST, Hanifin JM, Simpson EL, Boguniewicz M, Watsky KL, Lugo-Somolinos A, Hamann CR, Eberting CL, Silverberg JI, Thyssen JP A Pragmatic Approach to Patch Testing Atopic Dermatitis Patients: Clinical Recommendations Based on Expert Consensus Opinion. Dermatitis. 2016;27(4):186-92;

3. Boehncke WH, Wessmann D, Zollner TM, Hensel O: Allergic contact dermatitis from diphenylthiourea in a wetsuit. Contact Dermatitis 1997; 36(5):271;

4. Buus SK, Andersen KE Allergic contact eczema because of diethylthiourea in neoprene rubber Ugeskr Laeger. 2002 11; 164 (11): $1511-2$

5. Tuyp E, Mitchell JC: Scuba diver facial dermatitis. Contact Dermatitis 1983; 9(4):334-335;

6. Yang SL, Zhu GX, Yin SC, Chen HY, Zhang YQ, Lai W. Analysis of the results of patch test in 192 patients with hand eczema]. Zhonghua Lao Dong Wei Sheng Zhi Ye Bing Za Zhi. 2016, 20;34(10):770-772;

7. Boonstra MB, Christoffers WA, Coenraads PJ, Schuttelaar ML. Patch test results of hand eczema patients: relation to clinical types. J Eur Acad Dermatol Venereol. 2015;29(5):940-7.

\author{
Kmdr ppor. lek. Krzysztof Gadomski \\ Komandora Jana Grudzińskiego 4 \\ 81-125 Gdynia \\ aleks1973@interia.pl
}

